\title{
Media-reported corporate governance transgressions in broad-based black economic empowerment deals in the South African mining sector
}

\author{
Adèle Thomas
}

\begin{abstract}
The study explored the nature of publically identified corporate governance transgressions relating to deals designed to promote black economic empowerment (BEE) at 22 South African mining companies. A review of South African English language newspaper articles was undertaken for the period 1 January 2010 to 31 December 2011. Reported transgressions were assessed against a framework developed from relevant codes and legislation. Political interference/nepotism/fronting was the most-cited category of behaviour promoting governance transgressions, followed by fraud/ structuring of controversial BEE deals, and mismanagement/negligence. Public concern about governance of BEE deals in the mining sector and, accordingly, about the contribution of BEE to the broad socio-economic upliftment of historically disadvantaged South Africans, is highlighted.
\end{abstract}

Keywords: corporate social responsibility, boards of directors, emerging markets, empowerment, transformation, media

\section{INTRODUCTION}

After the advent of democracy in South Africa, in 1994, the government of the day designed various strategies to more equitably redistribute the wealth of the country, while simultaneously growing the economy (Mears, 2006). One of these strategies was black economic empowerment (BEE), targeted at members of the African, Indian, and Coloured ethnic groups, generically categorised as 'black,' and now more commonly known as 'historically disadvantaged South Africans' (HDSAs). However, a variety of terminology exists in the plethora of government documentation, legislation, and working papers (Davie, 2010), with the terms HDSA and black being used interchangeably. This paper uses the term HDSA.

\author{
Adèle Thomas \\ Department of Industrial Psychology and People \\ Management \\ University of Johannesburg \\ D Ring 429, Kingsway Campus \\ P.O. Box 524 \\ Auckland Park \\ 2006 \\ South Africa \\ T: +2711 7875344 \\ M: +27824538102 \\ E: adelet@uj.ac.za
}

Adèle Thomas is a professor who teaches, researches, and consults in the fields of business ethics and governance. She is particularly involved in researching governance in academia. 
Among the many problems that account for slow progress in bringing HDSAs into the economy through BEE strategies, poor governance in BEE practices, in general, has been noted (Terblanche, 2012), and, in particular, in the mining sector (Sartorius \& Botha, 2008; Ernst \& Young, 2013). This lack of meaningful transformation and the glaring disparity between rich and poor captured world attention in 2012 when wildcat strikes erupted at the Rustenburg-based Marikana mine outside Johannesburg, resulting in the death of more than 34 people, and leading to five months of wage strikes (Benjamin, 2013), which soon spread to other mines in the country.

Companies, government, and civil society share social responsibility obligations, particularly in emerging markets (Schlemmer, 2004) such as South Africa, to adhere to business practices that drive societal transformation (Tangri \& Southall, 2008), and to stimulate economic growth to address dire poverty (Fauconnier \& Mathur-Helm, 2008). In emerging markets, national systems of corporate governance are usually not well consolidated and institutionalised (Andreasson, 2011), and initiatives to promote corporate governance, in some instances, represent a "new development strategy" (Reed, 2002:223). However, since 1994, an advanced system of corporate governance has steadily evolved in South Africa, and, given the time span of 20 years, it could be expected that governance principles would prevail in decisions relating to partnerships, wealth distribution, and the general governance of BEE deals in a strategic sector that generates $18.7 \%$ of the country's gross domestic product (Chamber of Mines of South Africa, 2012).

\section{PROBLEM STATEMENT AND RESEARCH OBJECTIVES}

Studies indicate the role the media plays in governance control, largely through its monitoring function (Core, Guay \& Larcker, 2008; Dyck, Volchkova \& Zingales, 2008;
Wiesenfeld, Wurthmann \& Hambrick, 2008). Keightley (2011) cites numerous cases where the South African media has played a watchdog role in bringing instances of corruption to light, and following the progress of action taken in this regard. Bednar (2012) contends that the media often highlight governance issues that would otherwise be less noticeable to the public. Accordingly, the research question that the study sought to address was: What are the main types of corporate governance transgressions in the mining sector that have been highlighted in newspaper reports over a specific period of time?

The objectives of the study were, accordingly, (a) to identify broad areas of reported corporate governance transgressions in this sector, (b) to highlight the extent of importance accorded by the media to the types of reported governance transgressions, and (c) to consider these transgressions against a framework of best practice principles developed from relevant codes and legislation.

The focus of the study was on BEE deals, as media reports generally focus on specific cases, and on companies where it is conceivable that a sound overall governance strategy would have been developed, but that practices relating to certain deals evidence transgressions of such governance. Corporate governance transgressions not related to BEE deals were not considered in the study.

\section{LITERATURE REVIEW}

The literature review that follows commences with a discussion of terminology. Corporate governance in South Africa and its importance for the transformation of the economy is noted, whereafter broad-based black economic empowerment as a specific driver of economic transformation is considered. The literature review concludes with a profile of the mining sector in South Africa, within which the present study was located. 


\section{Terminology}

The broad concept of governance, with its components of responsibility and transparency, is essentially about ethical behaviour (Roman, Roman \& Boghiu, 2012). Corporate governance is concerned with "moral philosophy, values and norms of behavior that guide a corporation's behaviour within society" (Francis \& Armstrong, 2003:376), and is based on a system of ethics (Young \& Thyil, 2008). Corporate governance is also a means of structuring objectives and the manner in which they will be achieved and monitored in "ethically defensible" ways (Fleming \& McNamee, 2005:137). Diale (2010) stresses that organisational integrity is explicitly linked to ethics, crucial aspects of which are the absence of corruption and fraud, and adherence to accepted norms of organisational behaviour and decision making that puts public responsibility above private interests. Keightley (2011) cites kickbacks, nepotism, embezzlement, diversion of funds, illicit benefits or enrichment, and trading influence as major areas of corporate governance transgression in South Africa. Such corporate governance transgressions may also comprise legal transgressions, as in the cases of fraud and corruption, but, generally, such practices in organisations are viewed as transgressions of governance (Chau, 2011). In addition, behaviours and practices that may not necessarily be labelled as governance transgressions per se, such as political influence in business operations, may impact sound governance (Thomas, 2012).

\section{The role of corporate governance in the transformation of the South African economy}

South Africa is one of the largest and most sophisticated economies on the continent (Vaughn \& Ryan, 2006). The country is, however, still in the process of transition (Croucher \& Miles, 2010), necessitating sound governance (Detomasi, 2006). Fig (2005) notes the role of corporate governance in promoting the contribution of companies to the social development of those individuals who were historically disadvantaged.

Corruption negatively impacts long-term economic progress in developing economies, particularly where the institutional infrastructure to address such corruption is weak (Taylor, 2007), and where countries lack resources to investigate these problems (Keightley, 2011). Recognising the outside scrutiny of those who wish to invest in South Africa, extensive governance initiatives have been introduced over the past two decades (Vaughn \& Ryan, 2006) through various pieces of legislation and codes. The South African Constitution (Republic of South Africa, 1996) enshrines the concept of governance and the combatting of corruption, in that it articulates the basic values of justice, accountability, transparency, fairness, equity, and cost-effective and competitive business practices.

The Prevention and Combating of Corrupt Activities Act (Republic of South Africa, 2004) addresses the illegal offering and receiving of gratifications in any form, conflicts of interest, involvement in direct or indirect acts of corruption, accruing benefits from corrupt activities or gratifications, or influencing people to act in ways in which they abuse their powers, duties or functions. It also contains a provision for convicting those found practising corruption relating to contracts and the procurement of tenders.

Since 1994, a major influence on corporate governance in the country has been the three King Reports that detail and code best practices. Andreasson (2011) notes how this development has attempted to align corporate governance in the country with best international practices, while simultaneously addressing broadbased development. The latest King Report on Corporate Governance for South Africa (Institute of Directors (IoD), 2009), or King III, as it is known, is the blueprint for corporate governance in the country, and has been hailed internationally as an exemplary code to 
counteract corruption (Le Roux, 2010). It applies to both public and private entities, but is not legally binding. Particularly, it emphasises the importance of the triple bottom line (namely, the economic, environmental, and social components of company business) and ethics as a foundation for governance. It stresses the necessity of integrating corporate values into the strategies of companies, leading to the development of ethical corporate cultures. In this report, it is advocated that corporate governance must encompass the non-financial aspects of the company's operations, which include adopting strategies to promote the economic empowerment of HDSAs, protecting the environment, and contributing to society as a whole. The role played by leadership in the development of ethical corporate cultures is recognised, as are responsible corporate citizenship and the sustainable development of companies. King III is interlinked with compliance to the laws of the country and its regulatory environment.

On an international level, the Organisation for Economic Cooperation andDevelopment(OECD) issued the Principles of Corporate Governance, which has been acclaimed as an "international benchmark", a governance "reference tool" (Jesover \& Kirkpatrick, 2005:127), and one of the basic pillars contributing to international financial stability (Fülöp, Span, Pop \& Popa, 2010). The major points of each principle are expanded in Table 1 (OECD, 2004:17-25), and juxtaposed against the principles found in the South African Constitution, the Prevention and Combatting of Corrupt Activities Act, and the King III Report.

TABLE 1: Framework AgAinst Which to ASSESS CORPORATE GOVERNANCE

\begin{tabular}{|c|c|c|c|}
\hline \multicolumn{4}{|c|}{ Legislation and Codes } \\
\hline OECD (2004) & $\begin{array}{l}\text { SA Constitution (Republic } \\
\text { of South Africa, 1996) }\end{array}$ & $\begin{array}{c}\text { Prevention and } \\
\text { Combatting of Corrupt } \\
\text { Activities Act (Republic } \\
\text { of South Africa, 2004) }\end{array}$ & King III (IOD, 2009) \\
\hline $\begin{array}{l}\text { Principle One: } \\
\text { Macro context: Government } \\
\text { responsibility to establish } \\
\text { context to promote } \\
\text { transparent and efficient } \\
\text { markets; consistency with } \\
\text { laws; mix of legislation, } \\
\text { regulations, and voluntary } \\
\text { codes }\end{array}$ & $\begin{array}{l}\text { - Ensuring cost-effective } \\
\text { and competitive market } \\
\text { practices (Sect. 27[1]) } \\
\text { - Principles of justice, } \\
\text { accountability and fairness } \\
\text { (Sect. } 1 \text { [d]; Sect. 19[2]) }\end{array}$ & $\begin{array}{l}\text { - Duty to report corrupt } \\
\text { activities by anyone } \\
\text { who holds a position of } \\
\text { authority and who can be } \\
\text { expected to reasonably } \\
\text { know that an offence has } \\
\text { been committed (Sect. 34) }\end{array}$ & $\begin{array}{l}\text { - Companies are integral to } \\
\text { society and, as such, must } \\
\text { be well governed (p. 8) } \\
\text { - Good governance is linked } \\
\text { to compliance with the law } \\
\text { (p. 6) } \\
\text { - Good governance leads to } \\
\text { sustainable business, which } \\
\text { is a moral and economic } \\
\text { imperative (p. 19) } \\
\text { - Companies should } \\
\text { demonstrate good } \\
\text { corporate citizenship } \\
\text { to promote sustainable } \\
\text { development (p. 10) } \\
\text { - Principles of innovation, } \\
\text { fairness, and collaboration } \\
\text { (p. 13) } \\
\text { - Good governance } \\
\text { must promote social } \\
\text { transformation in society } \\
\text { (p. 13) }\end{array}$ \\
\hline $\begin{array}{l}\text { Principle Two: } \\
\text { Protection of shareholder } \\
\text { rights, to ensure transparency, } \\
\text { inclusion, and participation in } \\
\text { processes and decisions }\end{array}$ & $\begin{array}{l}\text { - No unfair discrimination } \\
\text { (Sect. 9) } \\
\text { - Principles of transparency } \\
\text { and fairness (Sect. 19[2]) }\end{array}$ & $\begin{array}{l}\text { - Ensuring non-corrupt } \\
\text { business practices (Ch. 2) }\end{array}$ & $\begin{array}{l}\text { - Principles of fairness and } \\
\text { collaboration (p. 13) }\end{array}$ \\
\hline
\end{tabular}




\begin{tabular}{|c|c|c|c|}
\hline \multicolumn{4}{|c|}{ Legislation and Codes } \\
\hline OECD (2004) & $\begin{array}{c}\text { SA Constitution (Republic } \\
\text { of South Africa, 1996) }\end{array}$ & $\begin{array}{c}\text { Prevention and } \\
\text { Combatting of Corrupt } \\
\text { Activities Act (Republic } \\
\text { of South Africa, 2004) }\end{array}$ & King III (IOD, 2009) \\
\hline $\begin{array}{l}\text { Principle Three: } \\
\text { Equitable treatment of all } \\
\text { shareholders, including their } \\
\text { rights of redress; prohibition } \\
\text { of insider trading; disclosure } \\
\text { by board members of } \\
\text { conflicts of interest }\end{array}$ & $\begin{array}{l}\text { - No unfair discrimination } \\
\text { (Sect. 9) } \\
\text { - Principles of equity and } \\
\text { fairness (Sect. 9) }\end{array}$ & $\begin{array}{l}\text { - Ensuring non-corrupt } \\
\text { business practices (Ch. 2) }\end{array}$ & $\begin{array}{l}\text { - Principles of fairness and } \\
\text { collaboration (p. 13) }\end{array}$ \\
\hline $\begin{array}{l}\text { Principle Four: } \\
\text { Recognition of the rights } \\
\text { of all stakeholders, and } \\
\text { cooperation between business } \\
\text { and stakeholders to create } \\
\text { wealth, jobs, and sustainable } \\
\text { enterprises }\end{array}$ & $\begin{array}{l}\text { - No unfair discrimination } \\
\text { (Sect. 9) } \\
\text { - Principle of fairness } \\
\text { (Sect. 9) }\end{array}$ & $\begin{array}{l}\text { - Ensuring non-corrupt } \\
\text { business practices (Ch. 2) }\end{array}$ & $\begin{array}{l}\text { - Good governance } \\
\text { protects the rights of all } \\
\text { stakeholders (p. 6) } \\
\text { - Inclusive stakeholder } \\
\text { approach (p. 9) }\end{array}$ \\
\hline $\begin{array}{l}\text { Principle Five: } \\
\text { Timely and accurate } \\
\text { disclosure of material matters }\end{array}$ & & & $\begin{array}{l}\text { - Transparent sustainability } \\
\text { reporting (p. 13) }\end{array}$ \\
\hline $\begin{array}{l}\text { Principle Six: } \\
\text { Board responsibility for the } \\
\text { ethical governance of the } \\
\text { company }\end{array}$ & $\begin{array}{l}\text { - No unfair discrimination } \\
\text { (Sect. 9) } \\
\text { - Principle of accountability } \\
\text { (Sect. } 1[\mathrm{~d}] \text { ) }\end{array}$ & $\begin{array}{l}\text { - No receiving or offering of } \\
\text { unauthorised gratification, } \\
\text { including money or favours } \\
\text { in kind, gifts, loans, fees, } \\
\text { rewards, valuables, security, } \\
\text { property or interest in } \\
\text { property, employment } \\
\text { contracts or services, or } \\
\text { avoidance of penalties, } \\
\text { discounts, commissions } \\
\text { (Sect. 10) } \\
\text { - Reporting of corrupt } \\
\text { activities relating to } \\
\text { contracts and tenders } \\
\text { (Sect. 12) }\end{array}$ & $\begin{array}{l}\text { - Good governance is about } \\
\text { effective leadership, } \\
\text { including developing } \\
\text { strategy to build } \\
\text { sustainable businesses, } \\
\text { considering the long- } \\
\text { term impacts on the } \\
\text { economy, society, and } \\
\text { the environment, doing } \\
\text { business ethically, and } \\
\text { considering the business } \\
\text { impact on stakeholders } \\
\text { (p. 19) } \\
\text { - Agreeing a governance } \\
\text { framework between the } \\
\text { group and its subsidiaries } \\
\text { (p. 30) } \\
\text { - Ensuring transparent } \\
\text { remuneration practices } \\
\text { (p. 31) } \\
\text { - Undertaking external and } \\
\text { internal audits (Ch. 7) } \\
\text { - Practising risk management } \\
\text { (pp. 35-36) } \\
\text { - Ensuring compliance with } \\
\text { laws, rules, codes, and } \\
\text { standards (pp. 5-6) }\end{array}$ \\
\hline
\end{tabular}

As a means of simplifying the framework, three broad principles, with their related manifestations, were extracted from Table 1 , and cover, without repetition, the issues raised. This simplified framework is presented in Table 2 . It is against these principles that governance transgressions in reported BEE deals in the mining sector are later assessed. 
TABLE 2: COMBINED PRINCIPLES AS A FRAMEWORK AGAINST WHICH TO ASSESS CORPORATE GOVERNANCE

\begin{tabular}{|c|c|}
\hline Principle & Guiding practice \\
\hline $\begin{array}{l}\text { Principle 1: } \\
\text { The macro environmental } \\
\text { context must promote } \\
\text { governance, sustainable } \\
\text { development, and } \\
\text { broad socio-economic } \\
\text { transformation }\end{array}$ & $\begin{array}{l}\text { - Government has a responsibility to establish a context to promote transparent and efficient } \\
\text { markets; consistency with laws; mix of legislation, regulation, and voluntary codes } \\
\text { - Good governance is linked to compliance with the law } \\
\text { - Principles of innovation, fairness, and collaboration should govern business transactions } \\
\text { - Cost-effective and competitive market practices must prevail } \\
\text { - Principles of justice, accountability, and fairness must prevail }\end{array}$ \\
\hline $\begin{array}{l}\text { Principle } 2 \text { : } \\
\text { The rights of shareholders } \\
\text { and all stakeholders, and } \\
\text { their fair and equitable } \\
\text { treatment must be upheld } \\
\text { to create wealth, jobs, and } \\
\text { sustainable companies }\end{array}$ & $\begin{array}{l}\text { - Principles of fairness, collaboration, and transparency must prevail } \\
\text { - Shareholders must be included, and participate in processes and decisions } \\
\text { - Non-corrupt business practices must prevail } \\
\text { - Insider trading is prohibited } \\
\text { - Full disclosure by board members and directors of conflicts of interests } \\
\text { - Full and accurate disclosure of material matters }\end{array}$ \\
\hline $\begin{array}{l}\text { Principle 3: } \\
\text { The board has overall } \\
\text { responsibility for the ethical } \\
\text { governance of the company }\end{array}$ & $\begin{array}{l}\text { - The company should not engage in any acts of corruption, which include the giving or } \\
\text { receiving of gratifications, including money or favours in kind, gifts, loans, fees, rewards, } \\
\text { valuables, security, property or interest in property, employment contract or services, or the } \\
\text { avoidance of penalties, discounts, and commissions } \\
\text { - Corrupt activities relating to contracts and tenders must be reported }\end{array}$ \\
\hline
\end{tabular}

A prime responsibility of boards of directors is to ensure sound corporate governance through the oversight role they play in monitoring senior managers of the company (Jones \& Welsh, 2012). This is particularly important as it pertains to Principles 2 and 3 in Table 2. It is for this reason that directors are judiciously appointed, governance processes and structures are instituted, and means of monitoring the organisation are established. In executing their fiduciary duties, boards of directors have to, in particular, monitor how the company impacts on society (Redmond, 2012), and how strategies such as BEE are executed (Khan, Muttakin \& Siddiaui, 2013). In essence, government has the responsibility to set the context for sound governance (Principle 1, Table 2), while boards of directors have the responsibility to ensure that Principles 2 and 3 (Table 2) are adhered to through the establishment of business practices that are beyond reproach. Through the actions of business and government, the principles noted in Table 2 are operationalised.

\section{BEE as a driver of economic transformation in South Africa}

In 1994, the newly elected South African government, led by the African National Congress, had to devise strategies to promote rapid economic growth and corporate investment to "break through the wall of whiteness around South Africa's economy" (Tangri \& Southall, 2008:699), as well as to drive broader social transformation (Hoffman, 2008).

The concept of BEE arose from a number of initiatives introduced to address the economic exclusion of the historically disadvantaged majority in the country. Measures to address black empowerment are mandatory for governmental and public sector institutions, and optional for private sector companies, unless they conduct business with government entities. Accordingly, in terms of its BEE clout, the size of the government market is considerable, representing $32 \%$ of the country's gross domestic product, rising as high as $50 \%$ if state-owned enterprises are included (Presidency, 2010). 
In the early days, BEE focused primarily on transferring equity ownership of big corporations to black managers through the acquisition of shares and black management representation in companies, primarily at senior levels (Hoffman, 2008). Particularly targeted were monopolistic conglomerates and those companies that historically promoted economic inequity (Rossouw, 1997). It was anticipated that this process would ensure the redistribution of assets, promote equitable opportunities for all, and advance the participation of HDSAs in the economic activities of the country. What emerged, however, was the rise of BEE equity 'sleeping partners' in established white businesses, with little involvement from them in the strategic management of such businesses (Tangri \& Southall, 2008), and a widening of the apartheid-created racial gaps in wealth (Ponte, Roberts \& Van Sittert, 2007).

As an attempt to address such concerns, in 2003, the Broad-Based Black Economic Empowerment (B-BBEE) Act (Republic of South Africa, 2003) was introduced. The Act aims to provide simplified guidelines that set out targets, roles, and obligations for the private and public sectors (BEECom, 2001). In addition, the Act was designed to include women, workers, youth, people with disabilities, and people living in rural areas. It was a formal attempt to regulate $\mathrm{BEE}$, to make it more inclusive and of benefit to the majority of the HDSAs of the country.

The Act provides for the establishment of sectorial transformation charters, tailored to the different economic sectors, to ensure that transformation progresses in measurable terms and according to codes of good practice. In this regard, BEE has evolved into an important institution that mediates the relationship between business and government (Hodgson, 2006). The disclosed value of BEE transactions in 2010 was in excess of R600bn (Presidency, 2010).

When the objectives of BEE are considered, and in spite of the related legislation, it appears that current BEE practices have shortcomings. Croucher and Miles (2010) add that, not only has BEE policy, as a concept, failed to progress empowerment among previously disadvantaged groups, but that this model of economic redress has become discredited. Thus, in its implementation, both BEE policy and the resultant practices have proved to be problematic, primarily because of a lack of political leadership (Croucher \& Miles, 2010). In addition, Lindsay (2011) notes that there is no consensus about the definition of BEE, and, accordingly, it has developed into a number of uncoordinated policies and programmes under the jurisdiction of some six separate ministries and based on a number of pieces of legislation.

Poor governance of business practices has also undermined BEE policy. South African media comment has focused extensively on corruption in the relationship between business and government that has developed as a result of BEE policy (Butler, 2010; Friedman, 2010). Several incidents have been recorded of HDSAs fronting for white companies where artificial partnerships have been forged in the name of BEE (Terblanche, 2012). An unintended consequence of awarding a tender based upon the highest BEE score is the participation in the tender process by only those who can afford to spend anything from R6 000 to R60 000 per year on a BEE audit (Terblanche, 2012). In addition, a slew of verification agencies have sprung up to address this need in the marketplace, estimated as being a R1.8bn a year industry with sometimes fraudulent misrepresentation of data to influence BEE scores (Iheduru, 2008).

\section{The mining sector}

The South African mining sector is dominated by six large mining houses or 'group producers' that grew throughout the 1960s to 1980s, largely through the infusion of Afrikaner finance capital (Capps, 2013:65). The ideology of apartheid was perpetuated through the development of large parastatals that serviced the energy needs of the mining industry through the introduction of favourable tariffs and pricing policies, and through the migrant labour system, which was a 
source of cheap labour (Capps, 2013). While the South African government adopted measures to bring about greater equity for HDSAs in this sector (Dansereau, 2010), Hattingh (2010) notes that the sector is still rife with racist attitudes and some of the worst working conditions and safety records in the world, leading to strikes and other forms of labour unrest.

The mining sector, valued at R20.3 trillion in 2011 (South Africa, 2013), includes 1600 mines employing around 840000 people (directly and indirectly), with capital expenditure exceeding R46.5bn, a tax contribution of approximately $\mathrm{R} 25.8 \mathrm{bn}$, and R16.2bn paid in dividends in 2012 (Doke, 2013). The majority of these mines are small, with only 53 companies listed on the JSE, of which only 25 are considered to be large players in the industry [personal communication $^{1}$.

Internationally, the risk factors involved in the mining sector are becoming more important, due to the nature of changes in the competitive investment and operational environments within which the sector operates (Ernst \& Young, 2013). The South African mining industry is in danger of being regarded as an investment risk, as the sector is viewed as one in which greater regulation must be introduced to address fraud and corruption (Ernst \& Young, 2013), practices that can impact a company's reputation, licence to operate, and bottom line (cf. MacMillan, Money, Downing \& Hillenbrand, 2004; McKinsey and Co., 2002).

\section{RESEARCH DESIGN AND METHODOLOGY}

The unit of study was the mining sector in South Africa. A qualitative approach was adopted. The approach attempts to explore a complex situation over a designated period of time,

1 Information supplied by Mr W. Tshabalala, Equity Market Division, Johannesburg Securities Exchange, 22 April 2013. within a specific context and setting (O'Leary, 2005), thereby promoting an understanding of that context (MacPherson, Brooker \& Ainsworth, 2000).

\section{Population and sample}

The population comprised all mining companies in the country. The purposeful sample included those 22 companies where corporate governance transgressions, linked to BEE deals, were identified in press reports during the period under review.

\section{Data collection and analysis}

The study made use of media reports of corporate governance transgressions in the mining sector. The media can be a powerful stakeholder in monitoring corporate governance in society, reflecting public concerns (Core et al., 2008; Dyck et al., 2008; Wiesenfeld et al., 2008).

All South African English newspaper articles contained within an electronic database, News Monitor, spanning a two-year period - 1 January 2010 to 31 December 2011 - were isolated. The News Monitor electronic library captures business news reported in leading newspapers and relevant specialist publications.

\section{Initial data analysis}

Franzosi (1987) first used content analysis for secondary newspaper data analysis by assigning "units of meaning" (Miles \& Huberman, 1994:58) to such data. This methodology has subsequently been used in similar studies (Danso \& McDonald, 2001; Magzamen, Charlesworth \& Glantz, 2001; Clarke, Evenett \& Lucenti, 2005). Through the use of key words, as advocated by Franzosi (1987), governance transgressions were identified. Key words included: governance, corruption, nepotism, cronyism, fraud, fronting, political influence, mismanagement, negligence, and entitlement.

Corporate governance transgressions relating to BEE deals were first identified in the News 
Monitor library by using the key words to highlight the incidents. The researcher was also supplied with an electronic version of all the newspaper articles from which the data were gleaned. The researcher then verified these findings by reading all newspaper articles and independently subjecting them to content analysis according to the key words. Only minor discrepancies were found between the number of 'mentions' of the incidences of governance transgressions noted by News Monitor and that identified by the researcher and, in each instance, the more conservative finding was accepted.

\section{Main data analysis}

After the initial analysis, a further two analyses were undertaken. Firstly, the number of mentions of corporate governance transgressions relating to one or more BEE deals for each company identified as a transgressor was recorded, to afford some insight into the importance the media (public) accorded such transgressions, which, in turn, reflects upon company reputation. More than one governance transgression per newspaper report was recorded in some cases. Secondly, data pertaining to the types of governance transgressions were grouped according to three broad thematic categories that emerged through content analysis, and the number of mentions according to these categories was noted across all companies (cf. Whitehead \& Kotze, 2003). To provide a qualitative dimension to the findings, where appropriate, substantiating comments that appeared in the newspaper reports were furnished. As the secondary data used in the study were in the public domain, no confidentiality was breached.

\section{RESULTS}

In the period under review, the News Monitor database identified 4416 mentions of corporate governance transgressions relating to BEE deals in general, spanning all economic sectors (see Table 3). Of these mentions, 155 (4.0\%) applied to the mining sector, and related to 22 companies within this sector.

TABLE 3: Media-REPORTED BEE gOVERnANCE TRANSGRESSIONS PER ECONOMIC SECTOR 2010-2011

\begin{tabular}{l|c|c}
\hline \multirow{2}{*}{ Sector } & \multicolumn{2}{|c}{ BEE governance transgressions } \\
\cline { 2 - 3 } & Number & Percentage \\
\hline Construction & 1317 & 30 \\
\hline Manufacturing & 921 & 21 \\
\hline Engineering & 850 & 19 \\
\hline Agriculture & 734 & 16 \\
\hline Telecommunications & 435 & 10 \\
\hline Mining & 155 & 4 \\
\hline Finance & 4 & 0 \\
\hline Total & $\mathbf{4 4 1 6}$ & $\mathbf{1 0 0}$ \\
\hline
\end{tabular}

Of the 22 mining companies (see Table 4), eight were listed on the JSE, with a further two linked to listed companies. In the case of six companies, foreign investors benefitted or had benefitted from the BEE deals. Two companies were liquidated at the end of 2011, due to extreme mismanagement, fraud, and corruption. One JSE-listed company, ArcelorMittal, accounted for the majority of the mentions of transgressions (77 or $49.7 \%$ ). 
TABLE 4: MEdiA MENTIONS OF GOVERNANCE TRANSGRESSIONS IN BEE INITIATIVES ACCORding to MINING COMPANY

\begin{tabular}{l|c}
\hline \multicolumn{1}{c|}{ Company } & \multicolumn{1}{c}{ Number of mentions } \\
\hline ArcelorMittal ${ }^{++}$(JSE-listed) & 77 \\
\hline Aurora Empowerment Systems ${ }^{*++}$ & 16 \\
\hline Imperial Crown Trading (JSE-listed) & 7 \\
\hline Kumba Iron Ore (JSE-listed) & 6 \\
\hline Alliance Mining Corporation (JSE-listed) & 5 \\
\hline Mvelaphanda (Mvela) Resources (JSE-listed) & 5 \\
\hline Sishen & 3 \\
\hline Afripalm Resources ${ }^{*}$ & 3 \\
\hline Acquarius Platinum (JSE-listed) & 3 \\
\hline ASA Metals ++ & 3 \\
\hline Wesizwe Platinum (JSE-listed)++ & 2 \\
\hline Genorah Resources & 2 \\
\hline Plasmeg & 2 \\
\hline Vryheid Revival Mines ${ }^{++}$ & 1 \\
\hline Emakhosini & 1 \\
\hline Harmony Gold (JSE-listed) & 1 \\
\hline Metallon & 155 \\
\hline Nakazi Mining Resources & 1 \\
\hline Richards Bay Minerals & 1 \\
\hline Rockwell Diamonds (JSE-listed) & 1 \\
\hline Shiva Uranium ${ }^{++}$ & \\
\hline Zululand Anthracite Collieries & 1 \\
\hline Total & \\
\hline
\end{tabular}

* Liquidated in 2011 ++ Non-HDSA involvement

Table 5 highlights the three broad types of governance transgressions that emerged from the content analysis. The first theme (political influence, nepotism, and fronting), relates to an interplay between the deals and larger external elements, such as government, political connection, and business strategy, to gain BEE credentials. The second theme (fraud and controversial deals) could be considered to comprise both legal transgressions and transgressions of governance, as these deals were fraudulently structured and surreptitiously advantaged those who are not targeted as beneficiaries of BEE. The third theme (mismanagement and negligence) relates to the daily operations of the organisation with regard to BEE deals.

TABle 5: Types of governance transgressions

\begin{tabular}{l|c|c}
\hline \multicolumn{1}{c|}{ Governance transgression } & Number of times mentioned & Percentage \\
\hline Political influence/nepotism/fronting & 119 & 56.9 \\
\hline Fraud and controversial deals & 56 & 26.5 \\
\hline Mismanagement and negligence & 35 & 16.6 \\
\hline Total & $\mathbf{2 1 1}$ & $\mathbf{1 0 0 . 0}$ \\
\hline
\end{tabular}




\section{Theme 1: Political influence, nepotism, and fronting}

The nature of corporate governance transgression that emerged in this category related to the use of influential political connections to unfairly secure BEE contracts. This appears to be the single greatest factor by far that leads to poor governance in such deals within the mining sector (56.9\%). Within this category, other mentioned transgressions included the complicity of historically white business in fronting, as well as the development of dominant elites, who are often in competition with each other to gain wealth through the acquisition of shares in these companies, with little further contribution to the management of such companies.

The following extracts serve to capture the essence of governance transgressions that are intrinsic to BEE initiatives that use political connections to serve the interests of an elite few.

Mokgata (2010:7) reported that Shiva Uranium chief executive Jagdish Praekh "hopes his newly acquired mine will benefit from the input of President Jacob Zuma's son, Duduzane Zuma as shareholder", to which Ndlangisa (2010:6) added: "This is tenderpreneurship [entrepreneurship based on the awarding of tenders] of a special kind, whereby government policies are used to open doors and the politically connected are the first to walk through.”

In a spirit of entitlement, it appears that these political elites may believe that the acquisition of wealth is something that is their due, and they often compete openly for opportunities to create such wealth. Masondo (2010:25) notes: "Access to the state provides [them] with leverage to select those who can acquire shares in white-owned firms ... The BEE model has promoted competition among politicians for access to institutional power..." Quoting Sindile Zungu, head of the Ayigobi consortium, which was given a $21 \%$ stake in ArcelorMittal South Africa, Salgado (2010:15) stated that she "admitted ... that the R9.1bn deal was "money for jam' for the consortium members who include individuals linked directly to President Jacob Zuma." Ndlangisa (2010:6) quoted the President of the National Federated Chamber of Commerce and Industry, Lawrence Mavundla, as having said: "I don't have a problem when people close to Zuma [the President] benefit because government positions are not permanent and they [people in government] don't get enough money to support their family members so that they do not have to work. They should be allowed to benefit because, at the end of the day, they are black."

\section{Theme 2: Fraud and controversial deals}

This was the second-largest mentioned category of reported corporate governance transgression (26.5\%). It involved practices that go against the spirit of the B-BBEE Act, including the manner in which BEE deals are structured and financed (which also constitutes legal transgression), the benefitting of foreigners or non-HDSAs through BEE deals, the exclusion of or disadvantage to communities in the setting up of BEE initiatives contrary to what is expected in the BEE policy, and dubious shareholder structures.

Illustrating the nature of fraud in some BEE mining initiatives, Dick (2010:12) notes: "ArcelorMittal, SA ... falls apart amid mounting allegations that its key partner, Imperial Crown Trading (ICT), engaged in fraud in its application for mining rights to the Sishen Iron Ore mine, [with] wide-ranging consequences."

Commenting on BEE deals being negotiated with non-HDSAs, Haffajee (2010:21) highlights two empowerment deals that "represent the arrival on our shores of predator post-colonial capitalism where political dynasties cream off the profits from developing economies, investing little and taking profits offshore. This is the polar opposite of what mining empowerment is meant to do... These politically connected young businesspeople are rented by foreigners and local businesspeople who know how cronyist systems work." 
Sergeant (2010:18) raises the issue of the quick turn-around time from the point at which a BEE partner acquires shares in a company and when he or she sells these shares at a profit: "Where deals have worked out, BEE participants have often been quick to sell ... One-time freedom fighter Mzilikazi Khumalo was the owner of R2bn in unencumbered shares. He sold the shares, raising close to R2bn in cash ... and now it seems that mining companies with successful prior deals and BEE partners who have sold out will simply have to do new deals all over again."

\section{Theme 3: Mismanagement and negligence}

This category was the third-most cited $(16.6 \%)$ with regard to corporate governance transgressions, and included: a lack of due diligence, the inability to repay restructured debt, the payment of exceptionally low wages or the avoidance of payment to employees altogether, an absence of risk management, and disregard for the environment.

Highlighting the plight of mine workers whose bosses are BEE partners, Qoza (2010:11) stated: "Khulubuze Zuma [son of the President] was the BEE highlight of the year. His empire spans gold mines in South Africa, oil exploration in the DRC [Democratic Republic of the Congo] and logistics with the South Koreans. In what can be viewed as an own goal for empowerment, workers at his mine went unpaid for nine months."

Marais (2011:1) continues: "After nearly two years of broken promises, extended deadlines, unpaid wages, suspicious deaths and a suicide ... Aurora [a mine owned by a BEE consortium, of which the President's son is a member] is not only responsible for the massive social crisis which impoverished more than 40000 people, but they also stripped the mining assets of all value and caused SA as an investment possibility immeasurable damage. Despite the non-payment of wages, it is estimated that Aurora made millions selling gold and scrap from the mines."

\section{DISCUSSION}

Corporate governance relates to the values and norms of behaviour of organisations as they function within society (Francis \& Armstrong, 2003; Roman et al., 2012). As such, when assessing corporate governance and corporate governance transgressions, it is important to ascertain whether behaviours and practices comply with the ethical standard expected by society. The direct transgressions reported in this study, and those behaviours that have led to governance transgressions, can be considered to contravene societal standards.

Reported corporate governance transgressions relating to BEE deals in the mining sector comprised only $4 \%$ of the number of newspaper reports of overall BEE corporate governance transgressions during the review period. One company (ArcelorMittal) was responsible for almost $50 \%$ of the reported governance transgressions in this sector. Nevertheless it remains that corporate governance transgressions were identified at 22 mining companies, eight of which are listed on the JSE, and a further two that are linked to listed companies. Highlighting governance transgressions at these companies, while not generalisable to all companies in the sector, serves to provide an indication of some of the problems that beset governance of BEE in this economic segment. It should also be borne in mind that practices such as political interference and controversial deals do not constitute governance transgressions perse. However, within the context of the present study, these practices had a direct impact on the governance of BEE deals, and led to poor governance practices (such as unfairly awarding a tender to a politically connected person, or promoting non-HDSAs as beneficiaries of BEE).

The findings are discussed within the context of the three broad principles presented in Table 2. 


\section{Principle One: The macro environmental context must promote governance, sustainable development, and broad socio-economic transformation}

It is incumbent upon government to structure the macro environment within which companies operate and within which BEE initiatives are undertaken, to ensure that it provides a milieu for good governance at country level. In this regard, the South African Constitution (Republic of South Africa, 1996), the Prevention and Combating of Corrupt Activities Act (Republic of South Africa, 2004), and the King III Code (IoD, 2009) have been widely acclaimed as containing the necessary elements to promote sound governance in companies and the country as a whole. A range of legislation, charters, and codes specific to the mining industry also endeavours to regulate BEE in terms of the objectives of this initiative. Thus, the foundation has been laid to promote sound corporate governance.

The most frequently reported category of transgression was that of political interference/ nepotism/fronting that promotes lucrative BEE deals to an elite group, some of whom are not HDSAs. In this regard, government officials and politicians, some close to the President of the country, blatantly flaunt their involvement in BEE deals that are well known to promote only the enrichment of an elite few (Tangri \& Southall, 2008). It is this transgression that strikes at the core of corporate governance, and which makes a mockery of BEE, designed to empower HDSAs who have been negatively impacted, socially and economically, by policies and practices instituted by the previous apartheid regime.

It appears that legislation and codes exist only on paper, and that the leadership of governance in some BEE deals is absent. In this regard, the principles of justice, accountability, and fairness, enshrined in the South African Constitution (Republic of South Africa, 1996), have not prevailed.
The mining sector is critical to the economy of the country, and it can be expected that flouting the law will, with time, create considerable reputational damage to the country (Ernst \& Young, 2013) and the mining companies themselves, thereby discouraging foreign investment. The scrutiny of foreign investors of governance practices in emerging markets is well known (cf. McKinsey \& Co., 2002; Vaughn \& Ryan, 2006), as is the negative impact of corruption on economic development (Taylor, 2007). In addition, investors could well be disinclined to invest in a market segment in which fair competition is stifled through favouritism, and where the basis upon which deals are brokered and mining licences are awarded is opaque (McMillan et al., 2004).

\section{Principle Two: The rights of shareholders and all stakeholders and their fair and equitable treatment must be upheld to create wealth, jobs, and sustainable companies}

Nepotism and political cronyism ultimately work against the empowerment of those who deserve to benefit from the redressing of past inequalities. To this can be added the practice of historically white-owned business being complicit in fronting with black partners in order to promote self-serving purposes related to business acquisition (Andreasson, 2006; Hoffman, 2008). The findings suggest that the rights of various stakeholders have not been upheld.

As noted above, government has not set the context within which those companies involved in corporate governance transgressions recognise their accountability to broad stakeholder groupings (Wieland, 2005). BEE, as originally designed, was intended to promote societal transformation (Tangri \& Southall, 2008), as well as to stimulate economic growth, to address dire poverty (Fauconnier \& MathurHelm, 2008). However, in line with Dansereau's (2010) belief that little has been done to promote equity for HDSAs in the sector, the practices of 
nepotism and cronyism can be considered to be corporate governance transgressions that directly act against the spirit of BEE. In such cases, companies present an outward display of transformation in response to the threat of nationalisation, but have not embraced the broad sentiments of BEE to reduce harm to those who work in the sector and to promote their social development (Dansereau, 2010; Fauconnier \& Mathur-Helm; Tangri \& Southall, 2008). In addition, the manner in which elites tend to benefit from BEE deals defeats the BEE objective, and it could be questioned how much of the scarce capital of the country could have been better invested in jobs, land, or houses for HDSAs.

\section{Principle Three: The board has overall responsibility for the ethical governance of the company}

Keightley (2011) notes that the concept of corruption is a complex one with both moral and ethical components, but one that broadly addresses irregular and unjust practices. From an institutional perspective, the concept includes the corporate governance transgression of failure by boards to ensure that business practices are impartial and transparent, including the failure to address practices that involve unjust personal gain through bribery, kickbacks, nepotism, embezzlement, illicit benefits, and "trading in influence" (Keightley, 2011:346).

Just over $43 \%$ of the governance transgressions mentioned was contained in the two broad categories - fraud and controversial deals, and mismanagement and negligence (Table 5). While overall governance structures may have been established, it is clear that the boards of directors of these companies are not exercising their fiduciary duty of ensuring sound and transparent governance. There was a lack of disclosure of conflicts of interests, the overlooking and acceptance of the giving and receiving of undeserved gratifications, and corrupt activity in the awarding of tenders.
Negligent management has seen company employees going unpaid for months, and, in the case of two companies, dereliction of fiduciary duty led to the liquidation of these companies within the review period.

In line with the South African Companies Act (Republic of South Africa, 2008) and the governance of companies that needs to prevail, all 22 mining companies were required to set up the relevant structures to monitor business practices. As such, it is an indictment of these boards that good governance was flaunted in the BEE deals structured and executed by these companies. In summary, it can be said that the boards of management of these companies, some of which are large players on the JSE, have been negligent in exercising their oversight role in the management of BEE deals (Jones \& Welsh, 2012). They have abdicated their responsibility for assessing and addressing the impact of company corrupt practices on stakeholders and broader society (Redmond, 2012), and for ensuring transparency in company practices (Keightley, 2011). In this respect, they have allowed the reputations of these companies to become tarnished, thereby potentially jeopardising investment in the sector.

\section{LIMITATIONS OF THE STUDY AND RECOMMENDATIONS FOR FUTURE RESEARCH}

Only those corporate governance transgressions in the mining sector that related to BEE deals reported in the South African English press during the period under review were recorded. Other unreported incidents of corporate governance transgressions could have existed outside these media reports, and media reports could also have contained bias in reporting. Human error could have been present in the qualitative judgment relating to the identification of reported corporate governance transgressions. The choice of key words to determine the News Monitor search, although guided by the literature and the numerous 
press reports on governance problems in BEE deals in general, could inadvertently have omitted key words, thereby erring on the side of conservatism in reporting on the full range of governance transgressions.

The findings were dominated by mentions of corporate governance transgressions that related to a few large companies, which may not necessarily reflect on governance within the sector as a whole. Therefore, the findings serve only to highlight issues of concern that have received public attention, and to afford some insight into the kinds of corporate governance transgressions that should be monitored by government and boards of directors.

The media has, however, been shown to highlight problems that might otherwise remain hidden (Bednar, 2012), and, spite of these limitations, the study does provide an indication of the broad categories of corporate governance transgressions that are of public concern. A more extensive study of the governance of BEE practices in this sector is recommended, and value could be gained by qualitative studies that explore the views of various stakeholders about the impact of governance in progressing BEE. A view could also be elicited from the managers who are tasked with operationalising the principles noted in this study in relation to BEE deals. In addition, a comparative study between the eight JSE-listed mining companies within which corporate governance problems relating to BEE deals were reported and the remaining 17 large companies listed on the JSE (which would have inevitably entered into BEE deals) where such problems were not reported could serve to broaden an understanding of how some companies ensure sound corporate governance in structuring and managing their BEE transactions.

\section{CONCLUSION}

The objectives of the study were to identify broad areas of reported corporate governance transgressions in the mining sector, to highlight the extent of importance accorded by the media to the types of reported governance transgressions, and to consider these transgressions against a framework of best practice principles developed from relevant codes and legislation. The contextualisation of the reported corporate governance transgressions against this framework provides some direction for a focus of intervention by both government and boards of directors.

While the BEE policy has been set up in a disjointed manner, it nevertheless remains that its principles, translated into practices, could serve to advance HDSAs in the economy. However, at the heart of the problem, whether formally labelled as corporate governance transgressions or not, are practices that ultimately impact sound governance in this sector.

The concept of corporate governance is central to any transformation initiative (Detomasi, 2006), as well as to social development in the country (Fig, 2005), and, it is argued, should be central to BEE strategies as well. For this to take effect, a marriage must occur between politicians who set the tone for sound governance and those directors of boards who are tasked with the fiduciary duty of monitoring the operations of companies. Until government recognises its responsibility, and until boards of directors experience the legal effects of dereliction of duty, actual corporate governance transgressions and practices that lead to such, as the ones reported in this study, will prevail. While legislation, charters, and codes of best practices are necessary, they are not sufficient in themselves to counteract the lack of fortitude in those who need to ensure that sound principles are translated into action that benefits those for whom BEE is intended.

\section{ACKNOWLEDGMENTS}

The financial contribution towards the data collection from the Faculty of Management, University of Johannesburg, is gratefully acknow- 
ledged. I would also like to extend thanks to Ms Ziyanda Makapula for assistance with the literature search.

\section{REFERENCES}

Andreasson, S. 2006. The African National Congress and its critics: 'Predatory liberalism,' black empowerment and intra-alliance tensions in postapartheid South Africa. Democratization, 13(2):303-322.

Andreasson, S. 2011. Understanding corporate governance reform in South Africa: Anglo-American divergence, the King Reports, and hybridization. Business and Society, 50(4):647-473.

Bednar, M. K. 2012. Watchdog or lapdog? A behavioral view of the media as a corporate governance mechanism. Academy of Management fournal, 55(1):131-150.

BEECom. 2001. Report of the Black Economic Empowerment Commission. Johannesburg: Skotaville Press.

Benjamin, C. 2013. Mining sector globally under strain. Mail and Guardian Business, 25-31 January:4.

Butler, A. 2010. From sports reporter to connected enforcer. [Online] Available: http://www.businessday.co.za/articles/ Content.aspx?id=131179 [Accessed 28 January 2013].

Capps, G. 2013. Victim of its own success? The platinum mining industry and the apartheid mineral property system in South Africa's political transition. Review of African Political Economy, 39(131):63-84.

Chamber of Mines of South Africa. 2012. Facts about South Africa's mining: Putting South Africa first: Mining's contribution to South Africa. [Online] Available: http://www.bullion.org.za/resources/ sub-categories/?section [Accessed 21 August 2013].

Chau, S. L. 2011. An anatomy of corporate governance. IUP fournal of Corporate Governance, X(1):7-21.
Clarke, J. L., Evenett, S. J. \& Lucenti, K. 2005. Anti-competitive practices and liberalising markets in Latin America and the Caribbean. World Economy, 28(7):1029-1056.

Core, J. E., Guay, W. \& Larcker, D. F. 2008. The power of the pen and executive compensation. Fournal of Financial Economics, 88(1):1-25.

Croucher, R. \& Miles, L. 2010. Corporate governance and employees in South Africa. Journal of Corporate Law Studies, 10 (Part 2):367-389.

Dansereau, S. 2010. Comparing duelling approaches to the transformation of South African mining: Corporate social responsibility or labour restructuring? Labour, Capital and Society, 43(1):65-98.

Danso, R. \& McDonald, D. A. 2001. Immigration and the print media in post-apartheid South Africa. Africa Today, 48(3):115-137.

Davie, K. 2010. SA and Latin America: The danger of populist economics. [Online] Available: mg.co.za/article/2010-1029-sa-and-latin-america-the-dangerof-populist-economics [Accessed 8 March 2013].

Detomasi, D. A. 2006. International regimes: The case of Western corporate governance. International Studies Review, 8(2):225-251.

Diale, A. L. 2010. The role and importance of whistle-blowing in building organisational integrity in the public sector: A theoretical exposition. fournal of Public Administration, 45(1.1):295-305.

Dick, W. 2010. Feeling the heat. Business Day Supplement:12.

Doke, L. 2013. Industry hits the right notes, but is it enough? Mining Indaba. Supplement to the Mail and Guardian, 15-21 February:1-2.

Dyck, A., Volchkova, N. \& Zingales, L. 2008. The corporate governance role of the media: Evidence from Russia. Fournal of Finance, 63(3):1093-1135.

Ernst \& Young. 2013. The business risk report: Mining and metals 2012-2013. [Online] Available: http://www. ey.com/miningmetals [Accessed 27 February 2013]. 
Fauconnier, A. \& Mathur-Helm, B. 2008. Black economic empowerment in the South African mining industry: A case study of Exxaro Limited. South African fournal of Business Management, 39(4):1-14.

Fig, D. 2005. Manufacturing amnesia: Corporate social responsibility in South Africa. International Affairs, 81(3):599-617.

Fleming, S. \& McNamee, M. 2005. The ethics of corporate governance in public sector organizations. Public Management Review, 7(1):135-144.

Francis, R. \& Armstrong, A. 2003. Ethics as a risk management strategy: The Australian experience. Fournal of Business Ethics, 45(4):375-385.

Franzosi, R. 1987. The press as a source of sociohistorical data: Issues in the methodology of data collection from newspapers. Historical Methods, 20(1):5-16.

Friedman, S. 2010. The worst threat to democracy that money can buy. [Online] Available: http://www.businessday.co.za/articles/ Content.aspx?id=92123 [Accessed 28 January 2013].

Fülöp, M. T., Span, G. A., Pop, A. \& Popa, I. E. 2010. The similitude and dissimilitude of OECD, Romanian and German corporate governance codes. International fournal of Business Research, 10(2):185-189.

Haffajee, F. 2010. Political dynasties keep the poor impoverished. City Press, 25 April:21.

Hattingh, S. 2010. Mineworkers' direct action: Occupations and sit-ins in South Africa. fournal of Labor and Society, 13:343-350.

Hodgson, G. M. 2006. What are institutions? fournal of Economic Issues, 40(1):1-25.

Hoffman, E. A. 2008. A wolf in sheep's clothing: Discrimination against the majority undermines equality, while continuing to benefit few under the guise of black economic empowerment. Syracuse Journal of International Law and Commerce, 36(1):87-115.

Iheduru, O. C. 2008. Why 'Anglo licks the ANC's boots: Globalization and state-capital relations in South Africa. African Affairs, 107(4280):333-360.
Institute of Directors (IoD). 2009. King Report on governance for South Africa. Johannesburg: Institute of Directors.

Jesover, F. \& Kirkpatrick, G. 2005. The revised OECD principles of corporate governance and their relevance to nonOECD countries. Corporate Governance: An International Review, 13(2):127-136.

Jones, R. \& Welsh, M. 2012. Toward a public enforcement model for directors' duty of oversight. Vanderbilt fournal of Transnational Law, 45(2):343-403.

Keightley, R. 2011. Fat cats, slim pickings: An examination of corporate corruption and the efficacy of existing countermeasures in South Africa. Journal of Contemporary Law Studies, 11(2):343-368.

Khan, A., Muttakin, M. B. \& Siddiaui, J. 2013. Corporate governance and corporate social responsibility disclosures: Evidence from an emerging economy. Fournal of Business Ethics, 114:207-223.

Le Roux, F. 2010. The application of the third King Report on Corporate Governance to small and medium enterprises. Research report submitted in partial fulfilment of the requirements for the degree Master's of Business Administration. Stellenbosch: Stellenbosch University.

Lindsay, D. 2011. BEE reform: The case for an institutional perspective. In J.Daniel, P.L. Naidoo, D. Pillay \& R. Southall (Eds.), New South African Review 2. Johannesburg: Wits University Press, 236-255.

MacMillan, K., Money, K., Downing, S. J. \& Hillenbrand, C. 2004. Giving your organization spirit: An overview and call to action for directors on issues of corporate governance, corporate reputation and corporate responsibility. fournal of General Management, 30(2):15-42.

Magzamen, S., Charlesworth, A. \& Glantz, S.A. 2001. Print media coverage of California's smoke-free bar law. Tobacco Control, 10(2):154-160.

Marais, J. 2011. Zuma Inc. hits skids. Business Times, 29 May:1-3. 
Masondo, D. 2010. BEE has evolved into a family affair: ZEE. City Press, 5 September:25.

McKinsey and Co. 2002. Global investor opinion survey. [Online] Available: http://www.mckinsey.com/ clientservice/organizationleadership/ service/corpgovernance/pdf/ globalinvestoropinionsurvey2002.pdf [Accessed 23 February 2013].

MacPherson, I., Brooker, R. \& Ainsworth, P. 2000. Case study in the contemporary world of research: Using notions of purpose, place, process and product to develop some principles for practice. International fournal for Social Research Methodology, 3(1):49-61.

Mears, R. 2006. The state of the economy as a basis for human development: Evaluated against the accelerated and shared growth imitative for South Africa. Africa Insight, 36(3-4):199-213.

Miles, M. B. \& Huberman, A. M. 1994. Early steps in analysis. In M. B. Miles \& A. M.Huberman (Eds.), Qualitative data analysis. Thousand Oaks, CA: Sage, 50-89.

Mokgata, Z. 2010. Shiva Uranium looks to fresh start with another Zuma link. Business Times, 23 May:7.

Ndlangisa, S. 2010. NUM blasts ArcelorMittal's BEE deal. City Press, 15 August:6.

O'Leary, Z. 2005. Researching real-world problems: A guide to methods of inquiry. London: Sage Publications.

Organisation for Economic Cooperation and Development (OECD). 2004. OECD Principles of Corporate Governance (revised ed.). Paris: OECD Publishing.

Ponte, S., Roberts, S. \& Van Sittert, L. 2007. Black economic empowerment: Business and the state in South Africa. Development and Change, 38(5):933-955.

Presidency. 2010. Development Indicators (2010). Pretoria: The Presidency of the Republic of South Africa.

Qoza, S. 2010. BEE flopped in its finest hour. City Press, 26 December: 11.

Redmond, P. 2012. Directors' duties and corporate social responsiveness.
University of New South Wales Law Journal, 35(1):317-340.

Reed, D. 2002. Corporate governance reforms in developing countries. Fournal of Business Ethics, 37:223-247.

Republic of South Africa. 1996. Constitution of the Republic of South Africa, Act No. 108. Pretoria: The Government Printer.

Republic of South Africa. 2003. Broad-Based Black Economic Empowerment Act No. 53. Gazette No. 25899. Pretoria: The Government Printer.

Republic of South Africa. 2004. Prevention and Combating of Corrupt Activities Act No. 12. Gazette No. 26311. Pretoria: The Government Printer.

Republic of South Africa. 2008. Companies Act No. 712. Gazette No. 32121. Pretoria: The Government Printer.

Roman, C., Roman, A. G. \& Boghiu, A. 2012. The new governance and globalization. Theoretical and Applied Economics, XIX(1):113-126.

Rossouw, G. J. 1997. Unbundling the moral dispute: About unbundling in South Africa. Journal of Business Ethics, 16:1019-1028.

Salgado, I. 2010. ArcelorMittal in R96bn BEE deal. The Star, Business Report, 11 August:15-16.

Sartorius, K. \& Botha, G. 2008. Black economic empowerment ownership initiatives: A Johannesburg Stock Exchange perspective. Development Southern Africa, 25(4):437-453.

Schlemmer, L. 2004. Business in change: Corporate citizenship in South Africa. Occasional Paper 2. Johannesburg: South Africa Foundation.

Sergeant, B. 2010. Govt. would do well to respect SA miners. Citizen - Money Web Business, 20 July: 18.

South Africa. 2013. Mining and Minerals in South Africa: Factsheet. [Online] Available: http://www.southafrica.info/business/ economy/sectors/mining.htm [Accessed 11 June 2013]. 
Tangri, R. \& Southall, R. 2008. The politics of black economic empowerment in South Africa. Journal of Southern African Studies, 34(3):699-716.

Taylor, S. D. 2007. Business and the state in Southern Africa: The politics of economic reform. Boulder, CO: Lynne Rienner.

Terblanche, B. 2012. Unpacking the draft rules of empowerment. Mail and Guardian Business, 19-25 October:7-8.

Thomas, A. 2012. Governance at state-owned enterprises. What do annual reports and the print media tell us? Social Responsibility fournal, 8(4):448-470.

Vaughn, M. \& Ryan, L. V. 2006. Corporate governance in South Africa: A bellwether for the continent?' Corporate Governance, 14(5):504-512.
Whitehead, T. \& Kotze, M. 2003. Career and life balance of professional women: A South African study. South African fournal of Human Resource Management, 1(3):77-84.

Wieland, J. 2005. Corporate governance, values management, and standards: A European perspective. Business and Society, 44(1):74-93.

Wiesenfeld, B. M., Wurthmann, K. A. \& Hambrick, D. C. 2008. The stigmatization and devaluation of elites associated with corporate failures: A process model. Academy of Management Review, 33(1):231-251.

Young, S. \& Thyil, V. 2008. A holistic model of corporate governance: A new research framework. Corporate Governance, $8(1): 94-108$. 